\title{
Radiografias da Prisão Feminina: um Mosaico
}

ANNA PAULA UZIEL ${ }^{I}$

\author{
SOARES, Barbara Musumeci; ILGENFRITZ, Iara. \\ Prisioneiras. Vida e violência atrás das grades. \\ Rio de Janeiro: Garamond, 2002.
}

Prisioneiras. Vida e violência atrás das grades mostra a prisão em três níveis, no intuito de cumprir seu objetivo, que é conhecer o universo para sugerir uma política penitenciária para as mulheres presas no Rio de Janeiro: apresenta os corredores dos estabelecimentos, oferece o percurso da instituição "prisão feminina" no Brasil e nos presenteia com dados muito recentes e instigantes, dos anos de 1999 e 2000.

A perspectiva de intervenção estava muito presente, norteando o trabalho, já que este foi desenvolvido no âmbito da Subsecretaria de Pesquisa e Cidadania, da Secretaria de Estado de Segurança Pública do Rio de Janeiro, em 1999. A segunda etapa foi desenvolvida pelo Centro de Segurança e Cidadania da Universidade Cândido Mendes (CESeC), criado em 2000, em função da saída da equipe da secretaria. Foi uma iniciativa inédita, que aproveitou a oportunidade de ter essa subsecretaria chefiada por um professor e pesquisador que pouco tempo depois teve que deixar o cargo. Um desafio se apresentava naquele momento: colocar diretamente o saber acadêmico à disposição de políticas públicas. Conhecer em detalhes a realidade da prisão feminina, como o livro demonstra, e intervir diretamente sobre as condições de execução das penas, pensar sobre a subjetividade dos cidadãos envolvidos sob múltiplos aspectos. Para tal, foram feitas visitas a unidades prisionais femininas e espaços de cuidados psiquiátricos do sistema penitenciário, pela própria equipe que coordenava a pesquisa.

O início do livro é um mergulho numa prisão. A realidade das descrições nos convida a um passeio por corredores e celas. As autoras iniciam o livro contando minuciosamente sua chegada na carceragem. Cada minuto da espera 
delas pela autoridade que não aparece remete o leitor à lentidão e ao descaso em que estão imersos a instituição e, em especial, sua população, e também aqueles que necessitam das autoridades para execução do seu trabalho. Além dessa vivência, os entrevistadores experimentaram o não-lugar atribuído aos que escapam das posições de mando, através de locais precários destinados à condução da pesquisa.

Se você já entrou numa prisão, sabe exatamente do que elas estão falando. Caso conheça apenas a realidade através da televisão, cinema ou imaginação, após a leitura da primeira parte do livro, será capaz de confundir pensamento e realidade, tamanha nitidez e intimidade.

O trabalho agrupa e analisa situações internas a cada estabelecimento, permitindo, através das diferenças e semelhanças, entender as lógicas, hierarquias, funções formais dos três estabelecimentos visitados. Analisa a relação das detentas com a comida, o abrigo dos filhos dessas mulheres encarceradas, a intimidade entre presas e policiais, o que muitas vezes nos obriga a recordar em que estabelecimento afinal foi realizada a pesquisa, tão grande a similaridade com outras relações de poder, submissão, contato físico que envolvem homens e mulheres.

As autoras analisam também os mecanismos que circundam o mundo do crime que se encontra na prisão, como a repetição e reprodução do encarceramento: por exemplo, filhos de pessoas presas são presos na idade adulta.

Atravessam o livro as incompatibilidades entre respeito ao ser humano e posição de poder, tão pregnantes no sistema prisional. Instituições como essa podem ser consideradas o extremo da capacidade em desconsiderar o outro como sujeito moral ${ }^{2}$. A desqualificação do outro o torna distante e diferente o suficiente para que o sujeito não considere seu ato como de crueldade ou desrespeito.

Em relação às unidades de tratamento de doença mental, a ausência de critérios para a admissão, fabricando a doença mental, a falta de estrutura, a arbitrariedade no contato com os usuários, a medicalização respondendo a necessidades institucionais reproduzem a realidade extramuros, com doses ainda maiores de negligência e abandono. Reproduzem, também, por motivos semelhantes, instituições psiquiátricas que compõem a outra face da moeda: as que recebem loucos não criminosos. Drogas, sexualidade, trabalho e religião 
são aspectos destacados pelas pesquisadoras, presentes no cotidiano carcerário. Depois de um tempo, entranhados por esses temas, familiarizados com o que se passa ali dentro, podemos falar sobre a prisão. Entremeados por aquela atmosfera, passamos a dados, nos enriquecendo com outra realidade.

Os dois outros capítulos do livro fornecem dados. A produção da singularidade de uma instituição carcerária feminina, as teorias da criminalidade próprias à mulher são coroadas com uma análise da realidade atual dos estabelecimentos.

Os primeiros dados de mulheres presas remontam ao final do século XIX. O material encontrado no início do século XX traz uma interessante distinção feita à época, entre as presas comuns, que cometeram crimes como infanticídio, furto, aborto, e as outras, contraventoras por vadiagem ou embriaguez, o que incluía prostituição. O risco de contaminação das primeiras pelas últimas retrata a moralidade presente na forma de compreender o crime. Era marcante a presença das elites e das congregações religiosas na condução das casas destinadas às mulheres detidas.

Curioso é que os argumentos que justificam a necessidade da criação de um presídio feminino se baseiam tanto na necessidade de separar as mulheres em função do tipo de infração cometido - e não é a gravidade que está em questão - quanto na urgência em separá-las dos homens. E a domesticação das mulheres vai ser pensada exatamente com auxílio da religião, estratégia diferente daquelas aplicadas aos homens, já que o objetivo da institucionalização era reconduzir a mulher ao seu destino doméstico e reprimir a sexualidade. Nesses moldes, nasceu no Brasil a primeira penitenciária feminina, em 1942.

Por fim, um tratamento cuidadoso dos dados mapeia perfil demográfico e sociocultural das presas e busca compreender o aumento significativo de mulheres presas no estado. Indo além, uma hipótese delicada é levantada pelas autoras: a relação entre participação em atividades criminosas e experiências de relações abusivas ou de ambientes familiares violentos na infância, juventude ou mesmo na idade adulta. Essa construção se fundou na identificação de situações de violência familiar e institucional presentes na vida dessas mulheres encarceradas, a partir de um questionário individual abrangente respondido pelas internas.

Os dados obtidos, relacionados a dados mais gerais sobre o crescimento da população carcerária como um todo, fornecidos pelo Ministério da Justiça, 
Censo Penitenciário, entre outros, articulados a informações da PNAD e pesquisas do Ministério da Saúde, fazem levantar hipóteses para compreender a situação feminina encarcerada atualmente. Os questionários aplicados parecem ter dado vida às informações genéricas da população em questão.

O cruzamento dos dados com uma análise das políticas de segurança do Estado do Rio de Janeiro desde os anos 1980 complexifica o quadro relativo ao tráfico de drogas. Uma análise dos mecanismos que envolvem o tráfico de drogas contribui para entender como a prisão acaba sendo um dos elos entre as violências por que passa boa parte das mulheres.

Retomando a hipótese delicada, não é objetivo das autoras inferir que situações de violência, ou mais especificamente de abuso, gerem ou induzam à criminalidade, discurso que facilmente se transformaria numa condenação a mais à pobreza, falta de escolaridade, modelos de família que escapem ao nuclear ideal. Ou ainda, um convite a novas hipóteses lombrosianas, ou utilizando-se do requinte da tecnologia e dos estudos de hormônios ou substâncias cuja função ocupem, no imaginário, um lugar mágico. Lança-se, com isso, um desafio, que é o do olhar cuidadoso para a existência concomitante desses fenômenos, da volta ou da permanência dessas mulheres em situações cujo pano de fundo se repete ou se perpetua na violência.

Uma das contribuições do trabalho, como as próprias autoras apontam ao final, é falar sobre a necessidade de olhar para essa instituição desprezível numericamente, se comparada à população masculina que habita o sistema prisional, mas que demanda esforços dos formuladores de políticas públicas.

O livro se compõe, assim, de múltiplas facetas a respeito da prisão feminina. Os três matizes se completam, formando um retrato complexo da realidade dessa população. Trata-se de completo, minucioso e instigante convite a conhecer essa realidade.

\section{NOTAS}

\footnotetext{
${ }^{1}$ Psicóloga, doutora em Ciências Sociais, professora adjunta do Instituto de Psicologia da UERJ, pesquisadora do CLAM/IMS/UERJ.

${ }^{2}$ COSTA, Jurandir Freire. Medo Social. Revista Veja - 25 anos. Edição Especial. Rio de Janeiro, 1993.
} 